\title{
Human Rights and the Widow's Material Security: The Case of the "Intestate" Ghanaian Widow
}

\author{
By David M. Dzidzornu
}

\section{Introduction}

Over the years, especially since the 1948 Universal Declaration on Human Rights was enunciated, many aspects of human life have been recognised as touching the essence of the dignity and welfare of life itself. That is why the more formal environment of "human rights", namely, the liberal vision that human rights consist essentially in the enjoyment of civil and political rights, has been expanded and surpassed by the incorporation of "economic, social and cultural rights" into the framework of human rights jurisprudence and practice.

An important aspect of the now expanded vision and notion of human rights deals with the place of women and the issues that peculiarly impact upon them in human rights practice. One of these issues is the extent to which married women are, or are not, materially secured as widows. This issue is important, inter alia, because the governing mores and norms of most societies are framed and expressed more from patriarchal, than from a balanced patri-matriarchal perspective. The manifestations of such predominant patriarchalism include the economic dependence of wives upon their husbands during marriage, and the virtual loss or non-recognition of their economic contribution to the valuables supposedly acquired by husbands during the subsistence of the marriage. In African countries where applicable patriarchal western legal concepts and practice have reinforced the dominantly patriarchal customary regime that governs this matter, the plight of the unsecured widow becomes stringently worse.

This paper is mainly concerned with the legislative efforts made in Ghana to circumvent and/or reduce the severe disability imposed upon a widow by customary law as regards her entitlement to a reasonable portion of her deceased husband's estate. The issue is considered as a national example in 'human rights practice'. It must be emphasised, however, that it is the internal recognition of the inequity of the family law in Ghana, rather than any signal influence of international human rights mores, which is the compelling motivation for the legislative changes under discussion. 
In Ghana, marriage can be contracted under custom, or under statute based on the English common law. However, since every Ghanaian belongs to a customary law system in which the rules of inheritance favour the wider family above the spouse, especially the widow, even where a statutory marriage is dissolved by the death of one spouse, the statutory rules governing succession to marital property in the absence of a will are, in practice, invariably undermined by the deference given to the applicability of the personal (customary) law of the deceased. The prevalence of this phenomenon works to greatly disadvantage the widow in particular.

The article posits the discussion in the context of the global and regional (African) rights regimes. The treatment of the "marriage life" of women in these regimes is analyzed so as to indicate the extent to which they could be said to lay the juridical and "inspirational" framework in which states may be expected to take the necessary remedial actions for their own systems. The consideration of the "African" context of this matter is not by any means comprehensive because, by necessity, only a sprinkling of examples from a handful of African countries is possible in this paper. The discussion and analysis of the Ghanaian case wraps it up.

\section{The Global Context}

The Charter of the United Nations (UN Charter) recognises, in its preamble, the "dignity and worth of the human person", and importantly, the "equal rights of men and women". It is its aim to promote the observance and respect of this equality and worth without distinction between, inter alia, the sexes.

The UN Charter bristles with provisions obliging member States to co-operate, as well as take individual steps to ensure the realisation of these aims and objectives. Thus, the standards which are enunciated as elaboration of the United Nations' commitment to human rights observance become pointers to the specific steps member States are expected to take to meet their Charter obligations in this respect. The Universal Declaration of Human Rights, 1948 (Universal Declaration), ${ }^{2}$ becomes the point of departure in this exercise of elaboration. Setting out general, but fairly comprehensive principles, the Universal Declaration proclaims itself as a

"common standard of achievement for all peoples and all nations, to the end that every individual and organ of society, keeping this declaration constantly in mind, shall

2 Gen. Assembl. Res. 217A (III), 10 Dec., 1948. For text, see International Human Rights Instruments of the United Nations, 1948-1982, UNIFO Publishers, New York,, 1983, at p. 5. 
strive by teaching and education to promote respect for these rights and freedoms by progressive measures, national and international, to secure their universal and effective recognition and observance ..."

It is thus clear that member States need not wait for every detail of what may be considered inequitable relations among their populations to be spelled out in an international instrument before they take steps to rectify them. Besides, the specific circumstances of each society demand localised methods of identif ying inequitable inter-personal relations, as well as locale-specific and locale-relevant remedies for their reversal. ${ }^{4}$ The basic jurisprudential assumption of international human rights law would therefore, perhaps arguably, be said to be the non-necessity of specific a priori formulation of notions and manifestations of "human rights" in conventions, instruments, declarations, etc., before they could be observed in practice. Thus, the recognition of inherent human dignity, and the moral and legal obligation upon individuals and State authorities to respect that dignity in daily life, is transcendental to any juridical postulates defining and codifying those rights, or for that matter, prescribing detailed and specific rules to secure their observance. However, the very historical background to the adoption of the Universal Declaration, and indeed every single human rights instrument and their monitoring and implementing institutions, volubly bespeak the glaring absence of commitment to observe human rights around the world. ${ }^{5}$

That is why it has always been argued that the Universal Declaration, for instance, has never inhered in legal authority and enforceability by itself. And that is why the rules of treaty law have applied to the signature and ratification of human rights conventions: the faculty to choose to be party to, or not, or to be party with reservations to specific rights provisions in these instruments, has applied with equal force to human rights instruments as to other international treaties. The former have never been treated differently simply because they may be said to enunciate principles and philosophies that are universally cognisable as applicable to all societies.

Thus, even if the obligation to observe and/or protect human rights is juridically characterised as a peremptory norm of international law from which no derogation is permitted, the specific content of observance as to specific postulates of the obligation in specific social

Id., preamble at para. 8 .

For an ongoing example of this effort, see Mohiuddin Ahmad / Clarence Dias (eds.), Promotion of Peace, Human Rights and Solidarity Among the Grassroots, Report of an Asian Workshop held at Saraburi, Thailand, May 1989; Clarence Dias, Rural Development, Grassroots Education and Human Rights: Some Asian Perspectives, in K.E. Mahoney / P. Mahoney (eds.), Human Rights in the Twenty-First Century: A Global Challenge, Dordrecht, 1993, p. 701.

This platitude is more than amply evidenced in the contributions in K.E. Mahoney / P. Mahoney (eds.), supra note 4. 
contexts remain largely indeterminable as a manifestation of that peremptory norm. So that if after over forty years the argument that the Universal Declaration is jus cogens can be sustained, ${ }^{6}$ still the value of its peremptoriness can consist only in the extent to which its specific principles, as enunciated, expressly or impliedly inform the concrete measures that States (and individuals) adopt to effect changes to inequitable social and interpersonal relations in law and in practice.

In this context, the particular contents of the Universal Declaration and all the other human rights instruments assume heightened significance in terms of the specific provisions they make regarding, for our purposes in this paper, the rights of female spouses.

Under Article 16 of the Universal Declaration, it is recognised, inter alia, that men and women are entitled to equal rights as to marriage, during marriage and at its dissolution. In addition, the protection of the family as the fundamental group unit of society is entrusted to both society and the State. Thus, this provision would impliedly demand, for example, that in the marriage context, neither spouse should be allowed, either by law or practice, to an arrangement, either immediate or contingent, that gives preferential security to his or her interest during marriage or at its dissolution. This 'equal security circumstance' between spouses is supposed to be ensured by both society and State. Both of these entities are said to recognise the fundamental indispensability of the family for their own existence. That being the case, it is clear that both society and State must take steps to ensure that either spouse be in a position to maintain the family at any epoch in the marriage relationship, including the period following the death of one spouse. Since it is axiomatic that most families include children, the implications of this provision are all the more significant.

Perhaps it is in view of the fundamentality of the implications of that provision that the global system sought to secure the marital instutution itself by, inter alia, requiring its registration. Under the Convention on Consent to Marriage, Minimum Age for Marriage and Registration of Marriages (Marriage Convention), ${ }^{7}$ it is categorically provided that "all marriages shall be registered in an appropriate of ficial register by the competent authority". ${ }^{8}$ The exercise of this authority by the State is an indication of its readiness to ensure that the marriages so registered are, during their subsistence and after, attended by the incidents that the provisions of Article 16 of the Universal Declaration would be said

For detailed discussion of the point, see, eg., Justice Muhammad Haleem, The Domestic Application of Human Rights Norms, in Developing Human Rights Jurisprudence, Commonwealth Secretariat Judicial Colloquium, Bangalore, 24-26 Feb., 1988, at pp. 92-108.

Convention, concluded on Nov 7,1962 , entered into force on 9 Dec., 1964. For text, see supra note 2 , at pp. 67-68.

Id., Article 3. 
to point to. For indeed, the Marriage Convention is predicated upon Article 16 of the Universal Declaration. ${ }^{9}$ Of particular import for our discussion is its recognition that "certain customs, ancient laws and practices relating to marriage and the family are inconsistent with the principles" set forth in the United Nations Charter and the Universal Declaration, and oblige States to take measures to abolish them. ${ }^{10}$ In other words, the universal system obligates States, through these flexible and general principles, to secure the place of spouses and by inclusive implication, children, in a family law regime and practice whose purpose should be to provide against pre-existing and contingent inequitable incidents in the marriage relationship as they affect either party.

Provisions in other United Nations instruments underscore the above point, especially as it relates to women. The Declaration on the Elimination of Discrimination Against Women, for instance, notes that where women are not treated as equal with men, the welfare of the family, the rearing of children and the development of the State in all areas are undermined. ${ }^{11}$ Article 6 of that Declaration therefore requires States to take steps to ensure that women have the right, inter alia, to acquire, dispose of and inherit property, "including property acquired during marriage". It is noteworthy that this Declaration makes no distinction as to which of the spouses acquires the property which the woman can inherit, so long as the property was acquired during marriage. On the other hand, the provision argues against the commonplace assumption that women cannot independently acquire property during marriage, or that they cannot be held as legally entitled to inherit their husbands' property.

These standards are further underscored by Article 16 of the Convention on the Elimination of All Forms of Discrimination Against Women. ${ }^{12}$ The Convention demands also that legislative and other measures be adopted to "modify or abolish existing laws, customs and practices", as well as social and cultural patterns of conduct which prejudice women, based as they are on the "idea of the inferiority or the superiority of either of the sexes or on stereotyped roles for men and women". ${ }^{13}$

Preamble to the Declaration at paras. $5 \&$ 6. See also Arts. 1-3. For text, see supra note 2 at pp. 103104.

Adopted 18 Dec., 1979,, and entered into force, sept. 3, 1981. Text in supra note 2, at pp. 150-154. Ghana, the central focus of this article, signes this Convention on 17 July, 1980.

Id., Articles 2 (f), 5 (a). This provision affirms the evidence disclosed by the case law arising from national and international enforcement of global, regional and national human rights instruments, that women's interests are inadequately protected in many areas relative to the interests of men; and it demands that the situation should change: see Rebecca J. Cook, International Human Rights Law Concerning Women: Case Notes and Comments, (1991) 23 Vanderbilt J. Trans. L., p. 779. 
Thus far, it can be observed as follows: firstly, that theoretically, these international instruments set forth the basic principles necessary to ensure that States act to remove the disparities between the circumstances that spouses find themselves in upon the death of one of them. It is common knowledge, however, that widows are more gravely disadvantaged than widowers in cases of intestacy.

Secondly, beyond setting forth the above principles, the global system hardly does much more. The Marriage Convention, for instance, does not require that States report on the concrete actions they may be taking to ensure the elimination, modification, reversal or otherwise, of customary laws and practices which, in the context of the family, work against women (or men). Each State is therefore left to go at its own pace in taking any such measures, if at all. More fundamentally, States are at liberty to accede, or decline to accede to the international instruments, and therefore to conform to them or not. But since individual nations' decisions an these matters are made under influences and considerations founded in domestic economic, political, social, religious and other factors and pressures, the inspiration offered by the universally desirable standards set out in the international instruments becomes of secondary import when the decisions have to be made. ${ }^{14}$ The Convention on the Elimination of All Forms of Discrimination Against Women provides for a Committee on the Elimination of Discrimination Against Women to consider national reports on the legislative, judicial, administrative and other measures adopted by States to implement the provisions of the Convention, and to make recommendations and suggestions thereon. ${ }^{15}$ In practice, however, the two weeks allotted each year for the Committee's work have proved to be a woefully inadequate time within which to consider even the reports that are submitted. Besides, the budget for the Committee's work is controlled through the United Nations bureaucratic system, such that the available funds cannot sustain work beyond the two-week period allotted under the Convention. ${ }^{16}$

For general discussion, see Abdullahi Ahmed An-Na'im (ed.), Human Rights in Cross-Cultural Perspectives: A Quest for Consensus, Philadelphia, 1992, passim. With specific reference to rights jurisprudence and practice in Islamic societies, see Abdullahi Ahmed An-Na'im, Toward An Islamic Reformation: Civil Liberties, Human Rights, and International Law, Syracuse 1990, Chps. 1, 6, 7 \& Conclusion; id., Islamic Law, International Relations and Human Rights: Challenges and Response, (1987) 20 Comell Int'1 L.J., p. 317. Regarding the context of Africa's reception and response to the matter, see Claude E. Welch, Jr. / Ronald I. Meltzer (eds.), Human Rights and Development in Africa, Albany 1984, Part I; Abdullahi An-Na'im / Francis M. Deng (eds.), Human Rights in Africa: Cross-Cultural Perspectives, The Brookings Institution, 1990, Parts 1, 2, 4 \& 5; Rhoda Howard, Human Rights in Commonwealth Africa, 1986, Chps. 1-2.

Supra note 12, at Arts. 17-22.

For a fuller discussion, see Theodor Meron, Enhancing the Effectiveness of the Prohibition of Discrimination Against Women, (1988) 84 Am. J. Int'1 Law, p. 213; cf. Kikka Pietila / Jeanne Vickers, Making Women Matter: The Role of the United Nations, London 1990, pp. 100-101, 123125. More generally, see Shelley Wright, Human Rights and Women's Rights: An Analysis of the United Nations Convention on the Eliminationof All Forms of Discrimination Against Women, in K.E. Mahoney / P. Mahoney (eds.), supra note 4, p. 75. 
It can therefore be firmly said that while the global system is obviously committed on paper to alleviating the innumerable inequities to which women are subjected in their marital lives, there is an almost conscious unwillingness to provide fully for the practical measures that will initiate and sustain the realization of the results envisaged by the goals set out in the human rights instruments.

\section{The African Regional Context}

Perhaps the limited initiatives of a global approach to the alleviation of problems of this nature can be excused by the fact that the global instruments themselves intimate that the onus of effort in attending to them must rest upon national and other agencies. In Africa, so-called peculiarities of human rights issues on the continent led to the adoption of the African Charter on Human and Peoples' Rights (African Charter) in 1981. These peculiarities are said to stem from the economic, social, political and cultural characteristics of a continent which has been free from colonial rule for barely three decades now. ${ }^{17}$

The African Charter declares itself as taking inspiration from the Universal Declaration, but does not consider that its principles should inevitably be interpreted in the light of all the other international instruments concluded pursuant to the Universal Declaration. This happens to be the case because, among other things, the African Charter accords supreme power to the working of national laws in human rights practice on the continent. These laws are allowed to determine the nature, scope and content of the various 'human rights' which individuals, groups, peoples and families can enjoy. ${ }^{18}$

For an overview of these issues, see Rhoda Howard, supra note 14, Chps. 1-4; Welch / Meltzer (eds.), supra note 14 , Part III, passim.

18

It is thus not surprising that the African Charter is likely to have only marginal influence on the domestic implementation of human rights on the continent. Tanzania and Algeria may seem to typify the situation. Tanzania ratified the African Charter on May 31, 1982, and incorporated its ever first Bill of Rights into its 1977 Constitution in 1984. The Bill of Rights became effective in March 1985, but it was not made justiciable until March 15, 1988. Since then, the enforcement of the rights guaranteed under the Bill has been done in deference to issues of national security, the interests of the ruling party, etc. As indicated in the text accompanying this note, the Charter's formulation of the guarantees of individual and people's rights would seem unable to find fault with Tanzania's way of observing the rights it guarantees under its constitution: see, C.M. Peter, Five Years of the Bill of Rights in Tanzania: Drawing a Balance Sheet, (1992) 4 Revue Africaine de Droit International et Compare [RADIC], p. 131; id., Human Rights in Africa: A Comparative Study of the African Human and People's Rights Charter and the New Tanzanian Bill of Rights (1990), esp. at Chp. 2; John Quigley, The Tanzanian Constitution and the Right to a Bail Hearing, (1992) 4 RADIC, p. 168. Similarly concerns of national security, the need to realize of national economic policy goals, and the supremacy of the powers of the President, condition the experience of rights guarantees in Algeria: Bouzid Lazhari, The Algerian Constitutional Experiment and Human Rights, (1991) 3 African Soc. of Int. \& Comp. Law Proc. [ASCIL], at p. 40. More generally for the continent, see Rhoda Howard, supra note 14, Chps. 5-7. The foregoing could be compared with Namibia which became party to the 
In this context, the protection accorded families and women becomes a matter of some interest. The African Charter places due emphasis on the fact that civil and political rights must be enjoyed simultaneously with economic, social and cultural rights. Naturally then, the family which has a central place in the sociological and juridical conception of African societies is declared to be the "natural unit and basis of society" to be protected by the State. ${ }^{19}$ Additionally, every individual is under a duty to "preserve the harmonious development of the family", and to work for its "cohesion and respect". ${ }^{20}$

The African Charter thus obligates both State and citizen to enhance the status of the family, and to secure its place as the founding unit of society, This obligation takes heightened significance in light of the recognition that the family is the "custodian of morals and traditional values recognised by the community". ${ }^{21}$ These are the standards that the African Charter sets itself to protect, among other things, and which it says should furnish its interpreters with principles to draw upon. ${ }^{22}$

As pointed out earlier, a central figure in the family is the woman. Her place in the African family system, particularly regarding inheritance from her family or from her husband upon the latter's death, is largely inequitable vis-a-vis that of her male relatives and her husband. In light of this, it is debatable how much an African woman can expect to be much better treated in the family system under both the customary and statutory law regimes of the countries which are party to the African Charter, simply because of that Charter.

The provision under the African Charter regarding women says as follows:

"The state shall ensure the elimination of every discrimination against women and also ensure the protection of the rights of the woman ... as stipulated in international declarations and conventions." 23

African Charter in 1992. Its constitution contains a Bill of Rights that reflects a commitment to liberal democratic protection of civil and political rights. So far, its Supreme Court has shown sensitivity to that objective, but it cannot be said how much the African Charter has contributed to this. For details, see Gino J. Naldi, Some Reflexions on the Namibian Bill of Rights, (1994) 6 RADIC, p. 45.

African Charter on Human and Peoples' Rights, Art. 18 (1). Text in (1982) 21 Int'l Legal Materials [ILM], p. 58.

Id., Art. 29 (1).

21 Id., Art. 18 (2).

For general analyses of the African Charter which came into force in Oct. 1986, see E. BondzieSimpson, A Critique of the African Charter on Human and Peoples' Rights, (1988) 31 Howard L.J., p. 643; C.M. Peter, Human Rights in Africa: A Comparative Study of the African Human and People's Rights Charter and the New Tanzanian Bill of Rights (1990), Chp. 3; Welch / Meltzer (eds.), supra note 14, part II.

Supra note 19, Art. 18 (3). 
Analysts looking at the extent of the protection accorded women under the African Charter are quick to point out that by referring to the applicability of other international rights instruments, the Charter makes African women the guaranteed beneficiaries of an extensive array of rights - civil, political, socio-economic, etc. They argue that the provision ensures, or at least indicates that African governments are committed to eliminate such abuses against women as genital operations, female child betrothal, and women's inability to acquire property independent of their husbands. ${ }^{24}$

Theoretically, that may be so. Indeed, in most African countries, constitutions and other statues provide for the equality of the sexes. Further, the majority of African States, including Ghana - have ratified the African Charter. But the contingent reality is that African States undertake, within the Charter system, to guarantee those rights to the extent that the modes employed to ensure their observance are consistent with, and draw upon the traditions and customs that exist within the societies of each State. This does not, by any means, indicate a commitment to let lie existing obnoxious customs and traditions. However, the overall context of the Charter guarantee of rights emphasises primary commitment to economic development. The State's assumption of an obligation to ensure the development of the family in Articles 18 and 29 is couched in the context. So that where it is possible to ignore customs which advantage men over women so as to ensure a peaceful climate for economic activity, the State is within its rights under the African Charter to do so. ${ }^{25}$

See eg., Winston Langley, The Rights of Women, The African Charter, and the Economic Development of Africa, (1987) 7 Boston College Third World Journal, pp. 215-221; Deborah Wean, Real Protection for African Women? The African Charter on Human and Peoples' Rights, (1988) 2 Journal of Int'l Dispute Res., p. 425. For general review of women's place under the scheme of rights enjoyment on the continent, see Rhoda Howard, supra note 14, Chp. 8; Welch / Meltzer (eds.), supra note 14 , Chp. 3.

25

It is not at all clear that Botswana, one of the parties to the Charter, was motivated by any economic considerations when in 1984, it amended its 1982 Citizenship Act. Under the 1984 amendment sponsored by the Ministry of Home Affairs acting on the recommendation of the Law Reform Committee, children born to a woman national of Botswana out of wedlock to a man who is not a citizen of Botswana qualify for Botswana citizenship. But if the partners are married, then the children born to them in wedlock do not qualify for Botswana citizenship. In other words, Botswana males can have children with foreign women in and out of wedlock and the children would have Botswana citizenship; Botswana women cannot. Notwithstanding well articulated opposition, the law passed, and would have remained on the statute books had Unity Dow, a Botswana woman married to the American Peter Dow, not complained that the law was unconstitutional and violated her rights, including her right to enjoy a stable family life with all her children, only one of whom was born before she married Mr. Dow. The Botswana Court of Appeal upheld her plea against the government: see E.K. Quansah, Unity Dow v. Attorney-General of Botswana - The Sequel, (1993) 5 RADIC, p. 189; Michael P. Seng, In a Conflict Between Equal Rights for Women and Customary Law, the Botswana Court of Appeal Chooses Equality, (1993) 23 The Univ. of Toledo Law Rev., pp. 563-582. Here was a clear case of a government intentionally refusing to protect the stability of family life contrary to its obligation under the African Charter, and doing so in a way that discriminates against women. If this is possible in the seemingly innocuous area of family life, then it cannot be vouchsafed 
Indeed, under the Charter as a whole, a careful balance is maintained between the rights of individual tribes to their economic and cultural development on the one hand, and the overall authority of the State to pursue the same goal. As well, the rights of minorities are subsumed to the overriding interests of the State, even though the rights of these minorities are not, thereby, necessarily suppressed. ${ }^{26}$ However, the important aspect of this arrangement is its clear statement that the main commitment of the States to the expected guaranteed observance of rights under the Charter lies more in ensuring national economic development, and if need be, by derogating from the rights of individuals, groups, etc. ${ }^{27}$

In the family context, the items that become the subject of inheritance are generally of important economic value. Among other things, they include land, other realty and cattle. In many African societies, women are not favoured to inherit these things from their husbands (and/or their fathers). It is thus obvious that protection for women within the regime of the law of the family is no more secure under the African Charter that it has been in the practice of the societies and States on the continent. ${ }^{28}$ For instance, Nigeria and Uganda are parties to the Charter. In both countries, the institutions of marriage and the traditional family remain central to the existence and functioning of the State. These institutions are largely regulated by customary juridical concepts, notwithstanding the intrusion of the common law which, in any case, exerts an essentially selective effort to

how consistently African courts would stand for respect of rights in situations where the stakes of political and other national interests may be higher. The examples of Tanzania and Algeria, supra note 26 18, point to the probabilities in those situations notwithstanding the African Charter

27 African Charter, supra note 19, at Arts. 19-24.

It must be appreciated, however, that partly for reason of the economic difficulties that African States continue to face, they are forced to derogate from their citizens' basic socio-political and other rights in order to carry through the economic measures dictated to them by international economic institutions. For them, therefore, rights observance or lack thereof is correlated, justifiably and/or excusably, or not, to their having to juggle complicated socio-economic circumstances against their in-principle acceptance of the obligation to uphold such rights: see, E.K. Quashigah, Protection of Human Rights in the Changing International Scene: Prospects in Sub-Saharan Africa, (1994) 6 RADIC, p. 93; Rhoda Howard, supra note 14, Chps. 3, 5-7; Welch / Meltzer (eds.), supra note 14, Chp. 12; AnNa'im / Deng (eds.), supra note 14, Chps. 7-9; cf. supra notes 17 \& 18.

This is more so given the fact that the Commission entrusted with overseeing and ensuring the observance of the Charter is confined under the political superintendence of the OAU Heads of State and Governments who determine the final outcome of any measures taken by the Commission against a State that violates a right secured by the Charter (Art. 53). Besides, only a handful of parties bother to send their largely superficial reports to the Commission regarding their implementation and observance of obligations under the Charter (Arts. 1, 21, 22, 25, 26, 62). In any case, the skeletal staff maintained at the Secretariat of the Commission in Banjul, its limited meeting times for attending to the business committed to it, and the financial and political restrictions under which it works do not augur well for its effectiveness as a continental human rights watchdog. For details, see Philip Amoah, The African Charter on Human and Peoples' Rights - An Effective Weapon for Human Rights?, (1992) 4 RADIC, p. 226. See also Rosalyn Higgins, Africa and the Covenant on Civil and Political Rights during the First Five Years of the Journal: Some Facts and Some Thoughts, (1993) 5 RADIC, pp. 55-66, regarding the marginal observance by African States of this global rights instrument. 
blunt the edge of the inequity that women face under the customary system. Even though the African Charter has been in force since 1986, it has hardly influenced these two States to take the measures necessary to harmonise practice under their customary regimes with their relevant common law and statutory rules.

Thus, in Nigeria, even though a woman's relationship to her husband's family is governed by the Marriage Act and customary law, in general

most women's lives are governed by customary laws and practices which subordinate [them]. For example in separation and divorce cases, women must introduce moral appeals to receive child support, despite the fact that the Act gives both parents child custody rights. Women generally are not concerned with legal proprietary rights or equitable entitlement to matrimonial property while married despite their substantial contribution towards the construction of the home. [Thus] problems arise when the man leaves, [because he can dispose of the property without considering the woman's input ... [and the difficulties she faces in seeking access to her interest or entitlement to the matrimonial property are graver when her husband dies]. ${ }^{29}$

The situation is not better in Uganda where "customary law is most of ten applied to matters of succession and inheritance to property". Practice under most of these laws is to the effect that

the widow is treated as the property of the deceased to be inherited as the wife of a male relative. If she refuses, she may be forced to return to her home. The deceased's home is usually given to the heir, who evicts the widow from the house. The rest of the deceased's property is usually shared among the male relatives. It is unheard of in some areas for a woman to inherit land or cows, both major economic resources in Uganda. There is a fear that she may remarry and the land or cows will go to another clan. Thus, when a woman's husband dies, she is deprived of all her deceased husband's property. ${ }^{30}$

These customs operate even though the Uganda Judicature Act provides that only customs which are not repugnant to natural justice should have the force of law in the country. ${ }^{31}$ Their continued operation is indicative of their overriding control and superior force in the family law regime, a force which African governments are slow to tackle for various reasons, including the political. This is why even where there are laws that entitle women to inherit their husbands' property either under will or upon intestacy, the inheritance does not accrue to the woman because, in practice, the customary rules which determine

Margaret Schuler (ed.), Women, Law and Development in Africa, WILDAF: Origins and Issues Series No. 4, 1990, at p. 25.

Id., at p. 50.

31

Id., ibid. 
succession overrule the statutory provisions. Even where a husband wills the property to his wife, customary successors and executors subject the will's dispositions to custom to determine its consistency with the latter. Conflicts and/or inconsistencies are resolved in favour of custom. ${ }^{32}$

It is important to note that the property in issue in these cases are not only personalties, but realties of proven economic value. A decisive intervention on the part of the State to enforce legislation seeking to secure the rights of the woman against the customary inheritors becomes an intervention of economic consequence which, in many cases, can lead to social commotion of a sort. Thus, the African Charter's leaning in favour of economic development as the primary right to be achieved does not encourage, let alone oblige State-parties to seriously pursue the rectification of these fundamental inequities affecting women as against men in the family context. ${ }^{33}$

The Ugandan situation is typical: Margaret Schuler (ed.), supra note 29, at pp. 50-53. However, in various African countries, judicial activity and legislation are making remarkable inroads into the hold of custom. In Ephrahim v. Pastory and Kaizilege (Tanzania High Court, 22 Feb. 1990, Civil Appeal No. 70 of 1989, reported in 87 Intl Law Reports, p. 106), Pastory had inherited clan land under will. In 1988, she sold it to Kaizilege. Ephrahim, Pastory's nephew, sought a declaration that the sale was void because under their Haya customary law, Pastory could not sell clan land. Justice Mwalusanya held that he could not af firm the continued operation of the Haya customary rule which entitled men to inherit and sell clan land, but did not give the same rights to women from the same clan. In his view, such a rule amounts to sex discrimination and flies in the face of the Tanzanian Bill of Rights and the international conventions that outlaw discrimination against women, treaties to which Tanzania is signatory. Cf. contrary attitude of the Tanzanian Court of Appeal in similar rights issues: C.M. Peter, supra note 18, at pp. 142-149. It should be noted that the right in contest in the Ephrahim decision is not between a widow and her husband's family. But the principle it establishes portends well for the situation in which a woman asserts a right of inheritance to her deceased husband's property, especially where statutory law supports her claim. This is so in Zimbabwe where incremental statutory remedies have provided against the deprivation imposed by custom upon widows as to their right to benefit from their deceased husbands' estates. The main difficulty - as in the case of Ghana, infra - is that the women and other entitled individuals are generally ignorant of these statutes and so do not avail themselves of their provisions: see Julie Steward, Who Gets the Money? Some Aspects of Testate and Intestate Succession in Zimbabwe, and: The Dependants Live On: Protection of Deceased Estates and Maintenance Claims, (1989-90) Vol. 7-8 Zimbabwe Law Rev., p. 85 \& p. 104 respectively.

This result is incongruous with Article 75 of the Treaty Establishing the African Economic Community, June 3, 1991, in (1991) 30 ILM, p. 1241. This treaty, aimed at ensuring that both Africa's men and women contribute their quotas to the continent's development, demands of member states in that Article to "formulate ... and establish appropriate policies and mechanisms for the full development of the African woman through the improvement of her economic, social and cultural conditions ... and to take measures necessary to ensure greater integration of women in development activities ...". Seeing that African women's contribution to the continent's economic performance from their relatively handicapped position is immense, the failure of the States to secure the women's access to economic resources out of political deference to inequitable customary rules would obstruct the realization of the economic objectives prioritized under this treaty and the African Charter. 
By way of preliminary conclusion, it can be said as follows:

1. That at both global and the African regional levels, the juridical principles demanding the protection of the material circumstances of a widow exist. These principles require decisive national action through the formulation and implementation of legislation to meet the obligation. The legislative and other measures taken in pursuit of this objective must undermine contrary customs, where necessary, especially in their enforcement.

2. That generally in Africa, the inequities that widows endure are bound up with their place as women in the social, juridical and economic contexts of their societies. These realities remain formidable and in many cases, entrenched in the conduct of societies so much so that African governments seem wary of disturbing the "hornet's nest" that they seem to be, presumably in favour of the peaceful pursuit of economic development.

Nevertheless, it must be emphasised that the adoption and committed implementation of ameliorative national legislation remains the most hopeful means of breaking the resilience of custom respecting this matter. Such legislation could make headway if its contents seek a compromise between customary law, particularly as it affects women, and the desirable ends that the State may wish to achieve within the framework of its international rights obligations. Seeing that African societies are largely rural, and the majority of its population unlettered, massive education campaigns would have to be conducted to familiarise the people with any such law. The institutional structures that this requires must also be provided. And, as a matter of tactic, flexibility must inform this process from the formulation of the legislation through to its implementation and enforcement. ${ }^{34}$

Ghanaian law has moved in this direction over the years. The rest of this paper looks at how far this move could be said to have made improvements to the fortunes of, especially, an intestate Ghanaian widow. 


\section{The Widow's Right of Intestate Inheritance Under Ghanaian Law}

The discussion here traces the development of the Ghanaian widow's succession to her intestate husband's property under customary law as tempered by judicial intervention, through to the changes introduced under statute.

\section{The Customary Law and the Courts}

The pristine doctrine of customary law regarding the relation of spouses as to the acquisition of property in Ghana is that while it is the "domestic responsibility of a man's wife and children to assist him in carrying out the duties of his station in life" - such as farming and business,

the proceeds of this joint effort ... and any property which the man acquires with such proceeds, are ... the individual property of the man. It is not the joint property of the man and the wife ... The right of the wife and the children is a right to maintenance and support from the husband and father. ${ }^{35}$

For this reason, when the man dies intestate, his self-acquired property becomes family property, i.e., the property of the wider family from which the man as an individual comes. The wife may not belong to that family. In the matrilineal societies of Ghana, the children do not inherit from that family. The more telling situation is that even if the wife belongs to that family, while she may have no right of succession to her husband's property in general, she has no ascertainable entitlement to any share of his property, and certainly not to his real property. ${ }^{36}$ Her only right is to be maintained by her husband's family. This right terminates when she is given in marriage to another member of the deceased husband's family, who then maintains her according to his own standard of life. If she chooses not to be so married, her husband's family's responsibility for her maintenance ceases at that point. Alternatively, that responsibility ceases also should the

Dictum of Ollennu J., in Quartey v. Martey \& Anor., [1959] Ghana Law Reports [GLR], p. 377, at p. 380. The legal validity of this proposition is doubtful, however: see generally, W.C. Ekow Daniels, The Ascertainment of Property Rights Between Husband and Wife, (1978) 10 Review of Ghana Law [RGL], p. 137; id., The Legal Position of Women Under Our Marriage Laws, (1972) IX University of Ghana Law Journal [UGLJ], p. 36; Akua Kuenyehia, Women and Family Law in Ghana: An Appraisal of Property Rights of Married Women, (1986-90 XVII UGLJ, p. 72, at pp. 79-80. Unfortunately, that dictum has been followed in a number of cases to deny a wife an interest in jointly acquired matrimonial property. For instance, in Adom v. Kwarley, (1962) 1 GLR, p. 112, the wife was denied a share in the house she helped her husband to acquire because the governing Akan customary law does not entitle to such a share. See also Gyamaah v. Buor, (1962) 1 GLR, p. 196. The position has not changed fundamentally, notwithstanding the courts' intervention on grounds of equity: see infra notes 38-43 and accompanying text.

Quartec v. Martey \& Anor., supra note 35, at p. 381. 
husband's family decide to give her a "send-off", ${ }^{37}$ usually a lump sum to help her settlein her new way of life.

With changes in economic and social circumstances, Ghanaian courts have recognised that the foregoing, and other incidents of customary marriage, especially the legal consequences attaching to the 'non-rights' of widows respecting their husbands' properties, cannot be held as remaining the same. This is because it has become common knowledge that in many cases, the contribution of the women to the acquisition of such properties goes far beyond their customary responsibility towards their husbands, even though the husbands happen to be invariably credited with sole acquisition of the properties in question. The need to temper the structure of the customary rules with notions of equity became more urgent in view of the fact that Ghanaian customary law does not have a doctrine of survivorship. For this reason, even if a couple acquired joint property, and there is evidence to prove the same, the presumption of customary law, particularly in practice if not in law, is that the husband's share of the property belongs to him without reference to the wife, and therefore devolves upon his wider family. ${ }^{38}$ The main reason for this result is the presumption that the husband would have made the larger contribution to the acquisition of the property - if not all the contribution - especially where the wife's contribution is not meticulously documented. ${ }^{39}$ In that situation, a wife (with her children) easily loses her right to a house she jointly acquired with her deceased husband. The consolation customary law gives her is to recognize her right of residence in the house built by her husband for the rest of her life under the sufferance of the husband's family.

In the early days of the courts' intervention in this matter, the main variation they made regarding this misfortune that the widow faced was a decree allowing her to choose to live elsewhere and to sub-let her accommodation in her husband's house and receive the

Id., ibid.

See Sarkodie J., in Abebreseh v. Kaah and Others, (1976) 2 GLR, p. 46, at p. 55. In the absence of a customary rule, the courts think that survivorship respecting matrimonial property could be presumed only with respect to household chattels. The presumption is that such chattels are the "joint property" of spouses with a right of "survivorship in the absence of any direct evidence as to who actually bought them". In other words, if it is known that it is the husband who bought them, the "interest of the widow and children should be limited to their use, and since [they] would be maintained by the customary successor ... out of that estate, they could not alienate any such property [especially fairly expensive self-acquired chattels like vehicles] without the consent of the deceased's customary successor or the family": per Edward Wiredu J., in In re Appiah (Decd.); Yeboah v. Appiah, (1976) GLR, p. 223, at p. 230. For further details, see Kwame Opoku, The Law of Marriage in Ghana: A Study in Legal Pluralism, Hamburg 1976, at Chps. X \& XI passim.

This was likely to have been the result in Abebreseh v. Kaah and Others, supra note 38, but for the overwhelming evidence adduced by the wife, with corroboration from witnesses familiar with the process of the acquisition of the property in issue. 
income accruing from it. ${ }^{40}$ Since then, however, the courts have added to their equitable reliefs for the widow: they have recognised her, and her children's, right to a possessory interest in the husband's self-acquired real estate, their entitlement to its quiet enjoyment, and in the appropriate case, exclusive possession over and above the interests of the husband's family. The courts emphasised that this right of possession passes on to the descendants of the husband through his children with the wife (or wives) in question. As well, they have recognised that household chattels such as furniture, refrigerator, kitchen utensils, etc., belong to the widow absolutely upon her husband's death intestate. ${ }^{41}$

As pointed out above, the courts adopted this 'progressive revisionary' attitude towards the concrete manifestations of the customary law because of socio-economic changes, and their recognition of the contribution made by customary law wives to whatever wealth their husbands acquired. ${ }^{42}$ But the important limitation to this piece-meal judicial inter-

40

Per Archer J., in In Re Kofi Antubam (Decd.); Quaico v. Fosu and Another, (1965) GLR, p. 138, at p. 145.

41 In re Appiah (Decd.); Yeboah v. Appiah, (1976) 1 GLR, p. 223, at pp. 229-230; cf. supra note 38 and infra note 48. More generally, see Akua Kuenyehia, supra note 35, at pp. 82-84.

42

The courts did exercise, and still exercise this discretion in cases where husbands die intestate, but especially in settling property rights between divorced spouses. Generally, they proceed by ignoring the system of law (customary or statutory) under which the marriage was contracted pursuant to Section 41 of the Matrimonial Causes Act, 1971 (Act 367). But they justify the exercise of this equitable discretion on two grounds: first, where the wife paid the purchase price of the property in question, notwithstanding that legal title was conveyed solely in the name of the husband. In that case, the husband is held as trustee of the wife's property: see Bulley-Neequaye v. Acolatse (unreported), digested in (1969) Current Cases, p. 51; Quist v. Brown, (1974) 1 GLR, p. 1; Yeboa v. Yeboa, (1974) 2 GLR, p. 114; Reindorf v. Reindorf, (1974) 2 GLR, p. 38. Secondly, they look for clear evidence that the wife made a financial contribution towards the purchase of the property, and irrespective of who holds legal title, the property is considered as jointly held between husband and wife: Quartey v. Armah, (1971) 2 GLR, p. 231. Indeed, the courts would even go behind a business registered in the husband's name to determine the wife's contribution to the initial capital, and her role in the generation of the profits and proceeds accruing from it: see the customary law marriage case of Domfe v. Adu, (1984-86) Ghana Law Reports Digest (GLRD), p. 77. Thus, when in Achiampong v. Achiampong, (1982-83) GLRD, p. 104, the divorced wife asked for a declaration of entitlement in one particular house belonging to the husband, the Court of Appeal demanded that she establish her direct financial contribution, or show that she applied her income for the benefit of their children and themselves thereby allowing the husband to acquire the property in dispute, or prove that there existed an agreement entitling her to the interest she claimed. But the Courts are slow to accord beneficial financial value, and by implication, proprietary interest to the domestic services of the wife where those services freed the husband to acquire property. The judicial attitude here is reminiscent of justice Ollennu's dictum in Quartey v. Martey, supra note 35, characterising the wife's services as not entitling her to any interest in property acquired by her husband, even if the property was acquired by their joint effort and was meant of their common use: Bentsi-Enchill v. Bentsi-Enchill, (1976) 2 GLR, p. 303; Odoteye v. Odoteye, (1984-86) GLRD, p. 61; cf. Ribeiro v. Ribeiro, (1989-90) GLRD, pp. 88 \& 89 (Supreme Court), which essentially extended proprietary value to the house duties of the wife, duties which spanned 34 years of marriage and allowed the husband to acquire extensive movable and immovable property. For more details, see Akua Kuenyehia, supra note 35, at pp. 94-98; Ulrike Wanitzek, Integration of Personal Laws and the Situation of Women in Ghana: The 
vention is that those widows who can afford to bring their cases to the courts are the only ones who may have any chances of overturning the destiny charted for them by customary law during their widowhood. And it should be emphasised that this marginal chance of benefitting from the equitable justice of the courts is not limited to only the illiterate customary widows. The death intestate of a husband exposes even the educated widows, who may have contracted monogamous marriages with their husbands under the English law-based statutes, to practically the same difficulties. This is largely because the signal influence of these statutes on family life is their observance more in the breach than compliance. To further complicate the matter, there is almost always a fairly close relationship between the individual spouses and their wider families, making the honouring of the man's family's pristine interest in the fortunes of 'their son' more probable when he dies. This is the context in which the large influence of custom must be appreciated. In it, the courts essentially become occasional commentators on a social dynamic whose negative influence on the lives of innumerable individuals they have not been able to do much about, in spite of their statutory power to the contrary. ${ }^{43}$

In the foregoing context, the most hopeful prospect for a widow benefitting from her deceased intestate husband under customary law would have been where the husband made an oral customary will, called semansiw. This will is, presumably, most common among the Akans, the dominant ethnic group in Ghana, which also happens to be predimonantly matrilineal. To be valid, the will must dispose exclusively of the man's selfacquired property, and be made in the presence of credible witnesses. These witnesses must hear the declaration and attest to its contents. It is also important for the validity of the will that it be made in contemplation of death. This does not mean that it has to be made only when the testator is about to breathe his last; it just has to be made as a last will and testament.

This oral will thus presents a 'judicial-customarily' valid opportunity by which a husband could make adequate provision for his wife and children. The provisions so made may not

Matrimonial Causes Act of 1971 and its Application by the Courts, (1993) Third World Legal Studies, p. 75, at pp. 86-105.

43

Under Section 20 of the Matrimonial Causes Act, 1971 (Act 367), the courts are given the power and duty to order property rights to be changed in divorce cases where this seems necessary for justice to be achieved. So far, they have not used this power creatively, preferring to stick to the common law and equity principles relating to disputes over matrimonial property. With this history, there is even less hope that they would be bolder where the property dispute involves a widow and the family of her deceased intestate husband. Probably Ribeiro v. Ribeiro, supra note 42, may have started an awakening away from this judicial inertia. See generally, Kwame Opoku, supra note 38 , ibid. See also Ernest K. Bankas, Problems of Intestate Succession and the Conflict of Laws in Ghana, (1992) 26 The Int'l Lawyer, p. 433, at pp. 433-446, where he discusses the case law and the limitations of judicial intervention relation to the inheritance of widows and children upon the death of a husband intestate. 
be disturbed by family members on any side, and proof of its existence makes it enforceable by the courts. 44

However, as pointed out above, the closeness between 'sons', expecially from the matrilineal ethnic groups, and the families they come from has more of ten than not meant that their inheritance matters are discussed with their family members rather than with their wives. As well, the witnesses who are most likely to be credible when they testify to the dispositions made are usually the man's family members who, of course, informally or otherwise influence the content to those dispositions. In any case, given the context of Ghanaian family life and the influence of the mores of customary inheritance, these declarations are not as common as would have been thought, nor are they always respected when made. ${ }^{45}$

Clearly then, not even from the semansiw source in the customary law of inheritance does a widow have much hope of retaining the standard of living she and her intestate husband may have attained by their joint efforts. This is why the legislative changes introduced have been of signal importance in the effort to reshape the legal regime on intestate succession in Ghana. We examine this next.

\section{Legislative Changes}

The courts' limited efforts have, over the years, been aided by specific legislation aimed at alleviating the hardship imposed by customary law on widows especially. Apart from the epoch-making, socially-responsive Intestate Succession Law, 1985, Section 13 of the

First of all, it must be noted that the customary law will as a personal juridical faculty and/or capacity does not seem to originate in the ancient past of the Ghanaian ethnic groups among whom it would seem to have become an institution of custom. More importantly, its current customary status and formal juridical standing, as well as the incidents that validate its execution have been developed preeminently by Ghana's modern courts basing themselves on the 'customary' indications of its 'primordial' existence and criteria of validity. In the process of their developing it, the judges have asserted its generalised applicability and/or application across the country. It is in cognizance of this that a legislation like the Intestate Succession Law, 1985, PNDC Law 111 (discussed below) assumes the form and content of a statute of general application aimed at the amelioration of a 'national' system of inequitable customary rules on testacy and/or intestacy. For details of the origins, the demographic spread and the judges' efforts in developing semansiw, see A.K.P. Kludze, A Century of Changes in the Law of Succession, in W.C. Ekow Daniels / G.R. Woodman (eds.), Essays in Ghanaian Law, Faculty of Law, Univ. of Ghana, 1976, p. 233, at pp. 234-235, $251--263$; K. Bentsi-Enchill, Intestate Succession Revisited I, (1972) IX UGLJ, p. 123; Akua Kuenyehia, supra note 35, at pp. 92-93; E.V.O. Dankwa, Property Rights of Widows in their Deceased Husbands' Estates, (1982-85) XVI UGLJ, p. 1, at pp. 2-4; Abenyewa v. Marfo, (1972) 2 GLR, p. 153; Abadoo v. Awotwi, (1973) 1 GLR, p. 393; Awotwi v. Abadoo, (1975) 1 GLR, p. 374.

See E.V.O. Dankwa, Progress and Regress in semansiw, (1978-81) XV UGLJ, pp. 97-112; id., supra note 44 , ibid. 
Wills Act, 1971, and a constitutional provision originating in 1979 and retained over the years have sought to address the issue under discussion. The latter two are discussed first.

\section{a) The Wills Act, 1971}

This Act is not, of course, meant to govern situations in which a husband died intestate. That is why its Section 13, which is relevant to this discussion, is important in showing the effort then made by the State to ensure that the death of a husband does not result in the automatic destitution of his surviving wife. As well, the provision is important since irrespective of whether a husband left a will, customary law inheritors are quick to secure what they consider to be their due before an "outlandish" document, as it were, disinherits them. How then does the Act treat a widow?

Under Section 13 of the Wills Act, 1971 (Act 360), the courts are given power to make "reasonable provision" out of the estate of a spouse (testator) for his widow (and father, mother and child). To benefit under this provision, a widow has to make an application within three years of the grant of probate of the husband's will. Beyond this, the High Court has discretion to make such a provision only if it thinks that the testator did not make reasonable provison for the widow either "during his lif etime" or "by the will". If this was so, the court has to be further convinced that should it fail to make such provison for her "needs", she would suffer "hardship".

This statute places obvious limitations on the chances of a widow recovering under it. For instance, if due to inability to afford it, or for some other reason she is not able to beat the time limitation on her right to apply, she has no further chance. On the other hand, should there be evidence that a wealthy husband made what the individual High Court judge may consider "reasonable provision" for her when he was alive, then it would not avail her even if she applies early. For, however, disproportionate the provision made by her husband for her in his lifetime may be in relation to the whole of the estate he disposed under the will, she remains automatically disqualified for any further provision if she could be said to have been reasonably settled by him. This limitation is especially unfair to a wife who may have been instrumental in the wealth build-up of her husband in important, even if intangible ways. As already pointed out, it is not uncommon, especially in Ghana's matrilineal communities, that by the influence of the interests of a man's family, the nature of the dispositions he makes under his will are actually discussed not with his wife, but with the principal members of his wider family. These are the people who become the administrators of his estate under customary law should he die intestate, and who, as already said, would naturally secure their customary interests, and probably more, even if he made a will. 
A further limitation is that once the court considers that the widow is not susceptible to material hardship in view of her circumstances, then, whatever the case, she is not entitled to any further provision out of her husband's estate beyond the dispositions in his will.

\section{b) Constitutional Provisions}

The time aspect of the limitations under the Wills Act was effectively removed by Article 32 (2) of the Constitution of the Republic of Ghana, 1979. That constitutional provision was retained under Section 24 of the Provisional National Defence Council (Establishment) Proclamation, 1981, the "legitimation Constitution" of the military government that ended the Third Republic operating under the 1979 Constitution. The provision requires that "no spouse may be deprived of a reasonable provision out of the estate of a spouse whether the estate be testate of intestate".

It should be observed that, in practice, Ghanaian courts cannot and do not look at succession to deceased husbands' properties only in the context of a family consisting of a husband, wife and children. The wider family always pursues its interests, especially where the property in question is reasonably substantial. Thus, even though the provision referred to above guarantees the right of a widow to apply to a court for reasonable provision out of her husband's estate at any time, nothing else is particularly guaranteed. Where it is a case of intestacy, the husband's wider family's interest is secured by customary law, one of Ghana's constitutionally-recognised sources of law, which the courts are seized to consider and apply. Where it is a case of testacy and the wife considers herself inadequately provided for, the court's discretion in what the final outcome of her application for "reasonable provision" may be cannot be lightly discounted; the exercise of that discretion cannot necessarily be expected to favour a widow over her husband's family. ${ }^{46}$

That is why it inspires little confidence that the current operative Constitution of the Republic of Ghana, 1992, retains this provision. In Article 22 (1), the Constitution provides as follows:

These observations are amply validated by the courts' handling of property settlement upon divorce, and in situations in which husbands died intestate: supra notes 40-43 and accompanying text. Clearly, apart from the time element, the constitutional provisions hardly guarantee any better chances of inheritance for a widow than did Section 13 of Act 360. Indeed, a wife who could not prove susceptibility to hardship if a court did not revise the provisions made for her in her husband's will would hardly persuade a judge that she was not reasonably settled by him. She would not be able to do the same if a judge is convinced that she would be served well enough by what customary administrators may have allotted her out of her husband's estate. 
a spouse shall not be deprived of a reasonable provision out of the estate of a spouse whether or not the spouse dies having made a will. ${ }^{47}$.

Prior to the coming into force of the 1992 Constitution, the then military government enacted the Provisional National Defence Council Law 111 (as amended) to unify or integrate legislation governing intestate inheritance irrespective of the system of law under which the marriage in question is contracted. Until changes or improvements are made to it, its innovative provisions govern intestate property inheritance in Ghana. We turn now to this law.

\section{c) The Intestate Succession Law, 1985}

In view of the limitations of the intestacy law as discussed, the Intestate Succession Law, 1985 (Provisional National Defence Council (PNDC) Law 111) could be said to have made a number of definite advances to the fortunes of a widow whose husband died intestate or partly intestate. By virtue of its Section 1 (1), Law 111 applies to all marriages contracted under any valid system of law in Ghana - statutory or customary. The Law's concern is the prospects of the material survival of the nuclear family of spouses and children, whenever one of the spouses dies. For this reason, it seeks to balance the interests of the wider customary law family, in preactice especially that of a husband, against the interests of his widow and children in the matter of succession to the property he may have left, or will leave at his death. To do this, Law 111 provides for two kinds of entitlements to the deceased spouses's (husband's) estate: absolute and residuary.

47 Articles 22 (2) \& (3) add provisions regarding spousal property rights during marriage and at its dissolution as follows:

22 (2) Parliament shall, as soon as practicable after the coming into force of this Constitution, enact legislation regulating the property rights of spouses.

22 (3) With a view to achieving the full realisation of the rights referred to in clause (2) of this article

(a) spouses shall have equal access to property jointly acquired during marriage;

(b) assets which are jointly acquired during marriage shall be distributed equitably between the spouses upon dissolution of the marriage.

Respecting the main subject-matter of this discussion, and property rights issues between living spouses, it is clear that until Parliament exercises its constitutional power to ground these matters in substantive legal rules that give definite parameters of decision-making to the courts, the unsatisfactory state of the law as discussed so far would remain the same. For, as shown in this discussion, issues relating to joint property acquisition and equitable distribution of the same are not easy to settle in Ghana's pluralistic legal system. 
First, the Law provides that where an intestate is survived by a spouse - in our case a widow - or child, or both, the spouse and/or child "shall be entitled absolutely to the household chattels of the intestate". These chattels include jewellery, clothes, furniture and furnishings, kitchen and laundry equipment, simple agricultural and hunting equipment, books, motor vehicles other than vehicles wholly used for commercial purposes, and household livestock. ${ }^{48}$ The widow and/or surviving child is or are also entitled to the house, should the estate in question include only one house. Where there is more than one house, she (and the child where applicable) is entitled to choose whichever one of the houses she may want. ${ }^{49}$

The foregoing provisions secure for the Ghanaian widow (and her child or children) the basic essentials they would need in the circumstances. Indeed, by these provisions, Law 111 would seem to ensure that virtually all the estate that most Ghanaian couples would have been able to acquire during the most productive and demanding years of their lives and marriage goes to the surviving spouse (most commonly widows) and the children of the marriage and/or household. ${ }^{50}$

\section{bb) Residuary Entitlement}

Beyond the foregoing absolute entitlements, the Law regards whatever may remain as falling into a residual category. It is from this lot that surviving parent(s) and the wider family are entitled to specified interests. There are three situations respecting inheritance

Intestate Succession Law, 1985 (PNDC Law 111), Sections 3 \& 18. These sections enact the equitable emendations that the courts have made to advance widows' chances of getting something out of their deceased husbands' estate: see supra notes $40 \& 41$ and accompanying text. They also overnule the limitation placed by the judges to the effect that a widow's interest in, for instance, a vehicle purchased solely by her husband is only usuf ructuary: see supra note 38 . Thus, even if such a vehicle is partly used for such commercial purposes as the typical Ghanaian 'after work taxi or charter' service, it should still fall within the category of household chattels to which she is entitled absolutely. Law 111 , Sections 4 \& 18 .

As paragraphs $2-4 \& 8$ of the Memorandum to Law 111 expressly state, the intention of the Law is to provide for a surviving spouse and dependent children. However, the definition of "child" in the Memorandum and in Section 18 of the Law lumps together non-dependent and dependent children. Further, the class of such children include those that the deceased husband may have had from (an)other woman/women. In practice, such a situation may limit the portion that the widow could enjoy, especially from a small estate where the older, non-dependent children may insist on their share as a matter of due entitlement, or as a form of revenge for reason that the widow in question may be seen as having displaced their mother, or for any other reason, even if they could do without their share from the estate. In any case, the more numerous the children that come within Sections $3 \& 4$, the smaller the widow's and dependent child(ren)'s portion: see W.C. Ekow Daniels, Recent Reforms in Ghana's Family Law, (1988) 31 Journal of African Law, p. 93., at pp. 97-98. Unfortunately, the amendment to Law 111, namely Law 264 of 1991 (discussed below), does not address this matter. 
to the residue. First, where there is a surviving widow (and her children), they are together entitled to $75 \%$ of the residue of the estate. A surviving parent receives $12^{1 / 2} \%$, and the remainder of the residue is distributed in accordance with customary law. But should there be no surviving parent, the $25 \%$ of the residue remaining outside the entitlement of the widow and children devolves under customary law. ${ }^{51}$

As a matter of customary law, children in patrilineal lineages should benefit from the distribution of the part of the residual estate that devolves under that law. However, it is easily foreseeable that the head and members of their fathers' families could argue that such children would have had enough from their absolute entitlement (with their mother) to the initial part of the estate, and from their share (with their mother) in the residue to make it indulgent for them to seek more at the expense of other family members. In the matrilineal communities, the prospects of any such extra benefit for the children does not arise. This is because, in those communities, children inherit through their mother's family, not their father's. ${ }^{52}$ In the circumstances, therefore, the statutorily-mandated absolute and residual portions secured to the widow (and children) would be their only inheritance if Law 111 is applied.

In comparison to the widow's (and children's) inheritance prospects under customary law alone as discussed above, Law 111's provisions on their absolute and residuary entitlements constitute a major 'rescue work' done for her benefit (with her child or children). In practical terms, it is quite obvious that where these provisions are reasonably well observed, the widow (and her children) would have enough by virtue of their guaranteed entitlements. Thus, it would probably make little or no material difference to their circumstances that (a) surviving parents(s) is/are allotted (b) portion(s) of the residue of the estate. ${ }^{53}$ It would be the same if they receive nothing from the residue that devolves under customary law.

The second situation under residual inheritance arises where the surviving spouse - widow - has no child. In this case, she receives $50 \%$ of the residue; $25 \%$ goes to a

Law 111 , Section 5 .

52 See A.K.P. Kludze, supra note 44, at p. 263; id., Restatement of African Law: Ewe Law of Property, London 1973, pp. 280-295 passim; cf. N.A. Ollennu, The Law of Testate and Intestate Succession in Ghana, London 1966, at p. 68.

53

As to (a ) parent(s)' entitlement to a share in their intestate child's property, it is imperative for any custom-revising statute like Law 111 to consider it as a necessary and beneficent variation on the otherwise absolute entitlement of widows and children to their husbands'/fathers' property. This arises from the fact that even in our increasingly individuated world, the very foundation of the Ghanaian family structure is the interlocking relationship of dependence by children upon parents, and vice versa. 
surviving parent and the rest falls for distribution under customary law. Where there is no surviving parent, the parent's residual portion devolves under customary. ${ }^{54}$

Thirdly, where the residue of the estate is small, the smallness being periodically determined in monetary terms by the Minister for Justice, the widow (and/or child) is absolutely entitled to all of it. ${ }^{55}$

\section{d) Law 111 and the Widow's Prospects of Material Security}

\section{aa) The Potential}

On the face of it, Law 111, as amended, could secure the material welfare of an 'intestate' Ghanaian widow. There are two main reasons for this. The first is that the Law applies in both statutory courts and in claims before chiefs or family heads. ${ }^{56}$ It its provisions are reasonably enforced in either forum, a widow would receive her just due from her intestate husband's estate.

The second reason arises from the widow's security of occupation of matrimonial home under the amendment to Law 111, the Intestate Succession (Amendment) Law, 1991

54

55

Id., Sections 12 \& 13. More generally on these rules of distribution, see W.C. Ekow Daniels, supra note 50, at pp. 96-99. The rules now incorporated under both the absolute and residuary entitlement provisions of Law 111 have had socio-historical and un-enacted legislative antecedents dating back to 1938. The early effort focused on extending Section 48 of the Marriage Ordinance, 1884, Cap. 127 as amended, to the distribution of the estate of all Ghanaians, whether married under customary law or statute. It was later thought that the provision in the Ordinance was inadequate to deal with the inequity inherent in the customary rules regarding a widow's non-inheritance of her husband. For, under Section 48, a third of the estate devolved under customary law, and the rest went to the surviving spouse (widow) and child(ren) of the Ordinance marriage. The problem was that the applicable English rules incorporated by Section 48 created a maze of cumbersome and complex formulae for distributing the estate such that the portions of realty and personalty that would fall to widow and children were, for the most part, virtually unviable in the context of inheritance involving a wife or wives and all the children acknowledged by the father as coming from within or outside his customary conjugal bond(s): see N.A. Ollennu, supra note 52, at pp. 247-252; K. Bentsi-Enchill, Ghana Land Law: An Exposition, Analysis and Critique, London 1964, pp. 173-188 passim; Kwame Opoku, supra note 38, at pp. 75-78. However, the principle of merit established by the Ordinance provision and the moves made to make it a rule of general application is that, it is imperative for the State to intervene in custom to secure widows and children especially, against their loss of access to and enjoyment of their husbands' and fathers' self-acquired property. This is what Law 111 has, on the whole, done far better than Section 84 of the 1884 Ordinance for both intestate statutory and customary widows and children. For an analysis of the socio-historical evolution leading to the rules in Law 111, see W.C. Ekow Daniels, supra note 50, pp. 94-95; A.K.P. Kludze, supra note 44, pp. 247 250.

56

Law 111, Section 21 (1). 
(PNDC Law 264). This amendment prohibits the practice whereby a husband's family members eject his widow(s) and children from the matrimonial home and remove as much of the estate as they can as soon as he is dead. Under Law 264, such ejection and removal of property cannot be done before the distribution of the estate, whether the husband died testate or intestate.

Law 264 makes it clear that the matrimonial home could be one of many. First, it could be the deceased husband's family house if he and the widow (and/or child) were living there at the time of this death. With respect to this premise, ejection of the widow (and/or child) would be unlawful if it is carried out earlier than six month after the husband's death. Second, the matrimonial home could also be the self-acquired property of the husband which he and the widow (and/or child) were living in at the time of his death, or any other of his self-acquired properties occupied by the widow (or child) at his death. Any ejection of the widow from any of the latter is unlawful ab initio and for all time. ${ }^{57}$ In other words, where a husband has more than one self-acquired house, and whether he and the widow lived together in the same one or not, no person is entitled to eject the woman from any of these properties before they are distributed. Similarly, where the man has houses enough for his child(ren) to occupy separately from him and his widow, while at the same time he and the widow may be living together in one of his houses, or in separate houses belonging to him, all such houses together fall for distribution as part of his estate under the category of matrimonial homes, and ejection of the widow and/or child(ren) from any of them is prohibited. ${ }^{58}$

The penalty for a conviction of unlawful ejection of a spouse (widow) or child, or for removal, destruction or other unlawful interference with the enjoyment of any part of the deceased's property to which they are entitled, is a fairly heavy fine or a maximum of a year's imprisonment. The courts can also order the reinstatement of, or reimbursement to the widow (or child) thus ejected or deprived. ${ }^{59}$

57

Intestate Succession (Amendment) Law, 1991 (PNDC Law 264), Section 1 (1). Cf. treatment of widow and/or child under customary practice as tempered by the courts, supra notes $35-41$ and accompanying text.

58

Law 264, Sections 1 (1) \& (2); cf. supra note 49 and accompanying text.

59 Law 264 , Section 2 . The maximum fine prescribed under this section is no more than US $\$ 500$ at current exchange rates. In real Ghanaian economic terms, however, it is a fairly heavy imposition. But more than the penalties is the fact that for the first time, the Ghanaian government commits its machinery to ensure that widows (and children) are not left without remedy should unscrupulous family members seek to wield their customary authority to deprive them of their lawful inheritance. Cf. inf ra note 69. 


\section{bb) Difficulties}

The foregoing beneficial potential of the Law is, at the moment, quite seriously undermined by a number of difficulties obstructing its efficacy.

The first difficulty can be stated as follows: that the Law's persuasiveness in matters of succession to property in civil tribunals under the jurisdiction of chiefs and/or family heads depends upon the acceptance of its precepts by these traditional authorities. As it is, Law 111 as amended undermines, particularly for family heads, a fairly rich source of their own sustenance. As a matter of fact, the large majority of intestate settlements are done under their authority and supervision. So that the fortunes of a widow in any particular case is largely dependent upon the appreciative understanding by the family official of the new legal regime, and more than that, his generous disposition towards the widow's circumstances. The probability that a widow could sue to enforce her statutory rights is not in doubt; but that again depends on a number of factors, including whether she knows she has any entitlement to her husband's estate guaranteed by statute, and whether she has placed herself in a position to assert her rights under the Law. ${ }^{60}$

The issue of the widow's knowledge of the Law, in the face of the resilient commitment by traditional authority to the norms of customary inheritance, constitutes the second and even more contingent obstacle in the way of the Law's efficacy. This is because most marriages in Ghana are contracted under customary law between unlettered parties. Even marriages contracted under statute are preceded by valid marriage ceremonies under custom, making them valid marriages under the two regimes. To come under Law 111 as amended, a customary marriage need not, but may have to be registered under the Customary Marriage and Divorce (Registration) Law, 1985 (PNDC Law 112), as amended by the Customary Marriage and Divorce Registration (Amendment) Law, 1991 (PNDC Law 263), both of which, on their terms, came into force comtemporaneously with Law 111 on June $14,1985$.

Under Section 15 of Law 112 as amended, the provisions of Law 111 as amended, apply to unregistered customary marriages provided that there is oral or documentary evidence satisfactory to a court or tribunal that a valid customary law marriage had been contracted between the deceased and the widow. Otherwise, following its celebration, such a marriage may be registered within a period specified under regulation by the Justice

60

For a discussion of the issue at a broader level, see Akua Kuenyehia, Fostering Rights Awareness Among Women - The Ghanaian Experience, (1991) 2 ASCIL, p. 73. 
Minister. In other words, there is no obligation to register a customary law marriage as a prerequisite for invoking the applicability of Law $111 .^{61}$

In light of the "mischief" sought to be remedied by the Law, the non-mandatory registration provision seems realistic since marriage registries are largely inaccessible to most Ghanaians, especially the rural folk. ${ }^{62}$ Thus, implicit in the combined legal regime created by Laws $111 \& 112$ as amended, is the fact that it will be quite a while before it becomes sufficiently known, and before facilities are provided for its implementation. In fact, the Justice Minister is, accordingly, given the discretion to "generally make provision [under legislative instrument] for the full implementation" of the provisions of the combined regime. ${ }^{63}$

It must be pointed out then that since knowledge of the tenets of the regime is fundamental to its efficacy, this statutorily-sanctioned 'delayed and gradual' dissemination, or as it were, 'implementation at large', becomes the definition of the lack of public awareness underlying its current inefficacy. For all this time that the regime has been in place, the State has barely educated the public, especially the unlettered customary law wives and family heads, as to their obligations and rights under Laws 111 \& 112 as amended. Consequently (and for reason of the other factors pointed out next), these Laws have not had the beneficial impact they were passed to bring about. ${ }^{64}$

61

Customary Marriage and Divorce Registration (Amendment) Law, 1991 (PNDC Law 263), Sections 2 (b) \& 6 (a). These provisions together say that though an application for the registration of a customary law marriage may be made "at any time after the marriage", the Justice Minister could "at any time" prescribe by legislative instrument periods within which failure to register the marriage constitutes an offence attracting appropriate penalties. No such regulations have so far appeared. The purpose of Law 111 as amended, makes in clear that penalties prescribed under Law 112 as amended, would aim at securing registration of such marriages, and not to exclude unregistered customary marriages from eligibility to the rights of inheritance guaranteed under Law 111. On this, see also Ekow Daniels, supra note 50, pp. 100 at 103. Indeed, lack of compliance with the registration requirements prescribed under the Marriage Ordinance, 1884, Cap. 127 and the Marriage of Mohammedans Ordinance, Cap. 129, have been construed by the courts as not invalidating a customary marriage: see Kwakye v. Tuba, (1961) 2 GLR, p. 720, at p. 724; Hausa v. Haruna, (1963) 2 GLR, p. 212; Coleman v. Shang, (1959) GLR, p. 390, at pp. 401-402; cf. Jebeille v. Ashkar, (1977) 1 GLR, p. 458, where late registration of a Moslem marriage between foreigners was held to have invalidated it. However, as discussed in this part, unless the more fundamental factors impeding registration are addressed, unregistered marriages would end up being excluded from the benefits of Law 111.

62

More than this, even over a year after the promulgation of Law 112, marriage registration forms were not available for use: see The Mirror, 11 Jan., 1986. And then, there has been the issue of high registration.fees which has been literally "debarring" people from going through the process: the People's Daily Graphic, 23 April, 1987.

63

Law 263, Section 6 (d).

64

It is ironic, but unnervingly consistent with national historical performance that educating the population to register their marriages is an Achilles' heel in the application and enforcement of Ghanaian family law. For instance, the application of Mohammedan law to regulate an intestate 
The third and probably most formidable problem obstructing the beneficial impact of the spousal property inheritance regime pivoted around Law 111 relates to the social status of the Ghanaian woman. In general, these women are contextually and socially less able to assert their rights and interests that are the men. Their place in society has evolved as one under an institutional system dominated by ideas and philosophies that give the leading role to men, whose interests are concomitantly better catered to. For instance, regarding the registration of customary marriages, Law 112 as amended authorises either spouse to have the marriage registered. However, any such registration would not be legally complete and valid without the signatures or thumbprints of both spouses. As well, since customary law marriages are potentially polygynous, Law 112 requires disclosure of other existing marriages where applicable. ${ }^{65}$ This gives the husband two opportunities by which to block the registration of a customary law marriage: first, a man who is unwilling to disclose to public authority the number of wives he has would discourage the registration as a matter of personal interest. Second, even where the marriage in question is the only one a man has, and intends to contract, he can block its registration by withholding his signature or thumbprint, a thing a wife is far less likely to do if her husband wished to register their marriage. Given this situation, the woman's independent statutory right to

Ghanaian Muslim's estate was, until the advent of Law 111, dependent upon the registration of such a marriage under the nineteenth century Marriage of Mohammedans Ordinance, Cap. 129. Unlike marriages under the Marriage Ordinance, 1884, Cap. 127 which, when contracted are also simultaneously registered in virtue of the record of them kept by the State, the potentially polygynous Mohammedan marriages were hardly, if ever, registered. By 1976, it had become sage to conclude that "the provision for the registration of Muslim marriages is ... a dead letter. Officers expected to carry out the registration ... probably do not know of its existence. Those who contract such marriages do not know of [the registration requirement]. One cannot remember when the last Muslim marriage was registered, or how many have been registered in the country since the enactment of the [Mohammedans] Ordinance": A.K.P. Kludze, supra note 44, at p. 251. See also Ekow Daniels, supra note 50, at p. 100. This historical national remissness has not been the change that should have been induced by the inheritance regime advented under Law 111. According to information obtained from FIDA-GHANA (a women's rights advocacy organization) in August 1994, knowledge of Laws 111 \& 112 has spread more by word of mouth than by any other means; that individuals who are aware of the laws let the women who have lost their husbands and are having a hard time with the latters' families know that they could be helped under the laws. The women then contact FIDA and other free legal aid institutions for assistance. More unfortunately, according to the same source, some of the women assume that registration of their customary law marriages under Law 112 confers upon them the status of "modern or civilized wives", the kind of social status implicitly accorded women who, since colonial times, marry under the Marriage Ordinance, 1884 (see also Kludze, supra note 44, at p. 244). This assumption not only beclouds the legal distinction between customary law and Ordinance marriages. It also shows that un-informed customary law wives may register their marriages for the wrong reason(s), and would not seek help under Law 111 when they need it, notwithstanding their having unquestionable loci standi to do so whether their marriages are registered or not. In light of this, the suggestion that Ghanaian lawyers (and other legal and non-legal public interest groups) should add to their traditional consultancy roles the task of systematically educating the women as to their obligations and rights under the Law is clearly justified: Akua Kuenyehia, supra note 60, passim.

Customary Marriage and Divorce (Registration) Law, 1985 (PNDC Law 112), Section 2 (3) \& First Schedule. 
register her customary law marriage is actually made dependent on her husband's consent to the registration.

To put this obstacle in perspective, it must be pointed out as follows: first, that under Section 3 of Law 112 the application for registration of a customary law marriage must be accompanied by a statutory declaration stating, inter alia, the names of the spouses and affirming that the marriage is valid under the applicable customary system. This declaration must be supported by both spouses' parents or persons standing in loco parentis to them, unless no such persons are alive at the time of the application for registration, a circumstance that would be extremely rare in an extended family-based society like Ghana where virtually every imaginable, rightly-related kin could legitimately act in loco parentis to spouses.

Second, it should be clear that no Ghanaian parent or relative would ordinarily swear to a false affidavit if no marriage took place. Therefore, a declaration from the parents or persons in loco parentis to either spouse is, and should be sufficient evidence of the celebration and validity of a customary law marriage, and so entitle either spouse to have it registered without the necessity for his or her partner's assent. As it is, the assent requirement means that a woman whose husband is opposed to the registration of their marriage would be reluctant to face registration officials' questions as to why her husband would not assent to the registration, and more painfully, as to whether there was in fact a marriage at all.

In the alternative, assuming that the requirement for the other spouse's assent were removed or waived under authority from the Justice Minister, ${ }^{66}$ it is still foreseeable that a husband would, either for personal reasons, or under the influence of his wider family in view of the implications of registration for their interests in his estate, oppose registration. Consequently, he would take whatever steps he might to ensure that his wife respects his disagreement with having to comply with the procedure. That he would succeed in having his was is guaranteed by the statute: Section 3 (2) of Law 112 intimates that the supporting affidavit of his parents or persons in loco parentis to him is indispensable for registration. This requirement gives him with his family the authority to be suitably uncooperative, and so frustrate his wife's effort to facilitate proof of their marriage for purposes of Law 111. This is the crux of the woman's social powerlessness and her subservient legal position in this matter vis-a-vis the contingent personal or family-influenced decisions of her husband.

Clearly then, this otherwise socially bold and laudable legislative effort aimed at facilitating proof of customary law marriages so as to protect intestate widows' entitlement to a

66

Cf. supra note 63 and accompanying text. 
reasonable portion of their deceased husbands' estates comes rather short. Consequently, the unfavourable 'inheritance' experience of widows at the hands of customary law is, in practice, left largely intact. The remedy that satisfactory oral evidence of a valid customary law marriage, having been contracted between a deceased intestate husband and a widow would bring the latter within the benefit of Law $111,{ }^{67}$ is obviously available only when proceedings are instituted either in court or before chiefs or family heads. But it is common knowledge that in Ghana people are slow to seek court remedies in all kinds of matters, and widows are particularly loathe to being at loggerheads with their husbands' families, more so when a head of family or perhaps a chief with interests which, on the right occasion, would be similar to those in issue before him, sits in judgment: a pseudo case of nemo judex in causa sua, or a real one?

Notwithstanding this 'litigation inertia', it cannot be lightly discounted that the juridical consciousness necessary to galvanise an individual to pursue and assert legal entitlements derives from the dominant legal consciousness in which society is steeped. It has been shown in the preceding discussion that as far as the legal regulation of the incidents of marriage in Ghana is concerned, the determinant system of legal consciousness is the customary law as society has come to know it, largely irrespective and independent of legislative, and the disproportionately small instance of judicial intervention. ${ }^{68}$

67

For earlier assessments of the prospects of the efficacy of law 111 in the light of the property rights of widows under Ghanaian law in general, see E.V.O. Dankwa, supra note 44, passim; Akua Kuenyehia, supra note 35, passim; also Kwame Opoku, supra note 38, passim. The inadequacies and inefficacy of statutory emendations to Ghana's family law have, over the years, been sharpened by the legal complications arising from inter-tribal marriages that demand the application of conflicting customary legal rules, a problem of internal conflicts of laws. The rules that exist for resolving these have also been inadequate, and as usual, the women lose out a lot. In view of this, and probably to get the courts to be more active in heading off this long-standing spousal inequity, Ernest Bankas, supra note 43, at pp. 447-464, suggests that Ghanaian courts should adopt Currie's "governmental interest analysis" theory, in combination with William Baxter's "comparative impairment methodology" when they are faced with cases turning on inheritance upon intestacy. Those two theories, he says, would combine to enable them to apply the customary law rules with which the surviving claimant is more closely associated and whose application to the inheritance matter in issue would be of greater advantage to the party and to the development of a sound conflicts jurisprudence. This suggestion may be of some advantage, especially in overcoming the constrained jurisprudence underlying Ghana's statutory law relating to the resolution of internal conflicts in the family law area. However, I think that in view of the problems that widows face in seeking judicial help to determine their rights to matrimonial property, Law 111, notwithstanding the difficulties in the way of its efficacy, has greater practical and contingent utility and relevance to the immediate and long-term concerns related to the widows' (and children's) inheritance upon intestacy, than a refurbishing of internal Ghanaian conflicts jurisprudence by theoretical embellishment. Clearly, Emest Bankas' failure to consider Law 111 regarding its relationship to his suggestion leaves the suggestion somewhat outdated, more so when the occasions on which the courts may be called upon to try out the approach he suggests would be so far between as to be irrelevant to the lives of the innumerable Ghanaians who have to contend with the vissicitudes of marital and family life in the meantime. 
This reality makes more inestimable the failure of the State to publicise this inheritance regime, or put in place the institutions that are supposed to implement it, especially in the country's majority, customary law-abiding rural societies which stand to gain immensely from its application and enforcement. The more these twin services called for by Laws $111 \& 112$ are left unattended to - as has clearly been the case since 1985 - the more marginally influential social legislation like these ones become as instruments in the reformation of national legal consciousness.

Therefore, whatever merits these legislative changes have will, for most Ghanaian men and women, be pitched against the dominant customary law of the family with all its demerits. From what has been said so far, it is clear that for the women, the uphill task of trying to secure entitlement to a fair portion of their intestate husbands' requires more than socially-responsive legislation to guarantee it. ${ }^{69}$

\section{Conclusion: The Human Rights Perspective}

In human rights terms, an 'intestate' Ghanaian widow's prospects of being materially secure is only marginally dependent upon the national laws which make provision for her in that respect. This is so even when, as discussed above, Law 112 is amended again to authorise her to register her customary law marriage with supporting affidavit from only her parents or relatives, and without having to secure her husband's signature or thumbprint. The true guarantee of her rights to the benefits she is potentially entitled to under Law 111, it has been shown, depends significantly upon her awareness of her rights under the legislation. Once she knows it, she would do her best to make sure that neither her husband's neglect or opposition, and/or that of his family, makes her an unwitting destitute in widowhood. Of course, the readiness of her husband to co-operate with her in bringing herself within the law, or failing this, and the willingness of her intestate husband's family to settle her in accordance with her statutory entitlement are also important guarantees of her right in this matter. Just like herself, her husband (whether formally educated or not)

69

It must be noted that even in those cases where customary law marriages have been properly registered, widows have to put up fights to ensure that their inheritance is not taken away by intermeddlers from their husbands' families acting illegally. In In Re: Isaac Nkansa Apau (Deceased), (unreported) Civil Appeal No. 93/90, 17 May, 1993, the brother of the deceased sold two of the deceased's cars to meet a pressing family commitment prior to the distribution of the deceased's estate. The Court of Appeal where the case ended, found that the cars would have gone "absolutely" to the widow and children under Section 3 of Law 111. Had the widow not pursued the matter thus far, she and her children would have been deprived of their inheritance without remedy. The Court of Appeal took the opportunity to observe that unless such intermeddlers are timeously brought to book, Law 111 would be undermined till it ceases to have any effect. This case is typical of the situation the women face, and symbolises the cost to society resulting from the failure of the State to ensure knowledge and respect for the laws it passes for the benefit of its citizens. 
and his family need to know what changes the statute has made to the customary law of spousal inheritance.

It is the postulate of rights jurisprudence that education and other facilities be available so that legal advantages such as those provided in Ghana's Intestate Succession Law may not be lost upon those who need them. But it is trite that the reality is a far cry from the postulate, as has been shown to be the case in Ghana in this matter. Unfortunately, that is the case for most women in most developing countries, not only in marital circumstances, but in practically all facets of life where the pursuits of their rights to basic dignity and personal security seems to be on an eternal collision course with social institutions that refuse to assimilate beneficial changes in social and legal mores, or even admit marginal emendations to their adverse features.

The solution or the alleviation of inequities of the sort discussed here rests more at the grassroots level. In the marital context, that grassroots is defined by the 'society of the two spouses'. The singularly weighty factor here is the attitude of the spouses, and respecting the Ghanaian intestate succession issue, that of the husband. A Ghanaian husband would settle his wife under will, or under the regime of Law 111 if he wants to. What he needs is to overcome the long-standing socio-cultural and psychological orientation that tells him that his wife's right to his material provision comes second to his extended family's because she may or does not belong to that family. And then, in dispensing his material possessions, to maintain a balance between his commitment to his extended family, and his more irrevocably prior obligation to his own family of wife (or wives) and children. The State's role to help through with this process of psycho-cultural reorientation and personal priority reorganization on the part of a Ghanaian husband consists in helping him see how easy the regime of Laws $111 \& 112$ have made his task.

The Ghanaian State's failure to make noticeable headway in this area since 1985 underscores one matter of importance: that in reality, the marital complementarity of spouses (and in prior contemplation, the social equality of male and female) is not accorded its due respect and legal protection. This is how the openly expressed or implicit social subservience of the female's interests to that of the male is entrenched. In this context, legislation such as exists to regulate spousal inheritance in Ghana is of limited value to the female. This is because the male partner who wields the greater influence within the conjugal bond is more likely to decide when, and how, the female partner takes advantage of such laws. Clearly, this def eats the results expected to be secured by legislation such as Law 111.

70

For a general survey, see Margaret Schuler (ed.), Empowerment and the Law: Strategies of Third World Women, OEF International, 1986, passim; id., Women, Law and Development: Action for Change, Origins and Issues Series No. 2, 1990, passim. 
In conclusion, it must be said plainly that as a matter of human rights observance, the probability of the Ghanaian widow's material security coming from the estate she worked with her deceased husband to acquire largely remains a tenuous proposition of social and legal reality to the extent that customary law reigns superior to government legislation in the regulation of this aspect of the family law. Of course, this is not an irreversible situation: The State's failure to undertake the tasks mandated by its own laws leaves the field open for individuals and the various women's and other social organizations in Ghana to step in. In any case, no government anywhere succeeds in the implementation of any social legislation all by the efforts of its agencies. Laws $111 \& 112$ give all Ghanaians the chance to see to it that our widows and children have memories of fathers who ensured their basic survival even from beyond. 
group of people who, because they had benefited from running the party and state, became accountable only to themselves; they were unresponsive to the wishes of the people.

The Nyalali Commission, as it has come to be known, made over one hundred and fourteen recommendations to the government to guide the transition and to facilitate the functioning of a widely accepted democratic regime. Some recommendations were taken up quickly, but very many others were not and, by deciding not to issue a White Pater on the report, the government has purposely tried to stymie discussion on the recommendations. The paper argues that it is understandable that the state would like to avoid chaos by managing the transition tightly. However, this management seems to be influenced too much by partisan interests, to the extent that a very good opportunity is being missed to put a broadly-accepted and working democratic regime in place.

\section{Human Rights and the Widow's Material Security: The Case of the "Intestate" Ghanaian Widow}

\section{By David M. Dzidzornu}

Essentially, the predominant customary system of inheritance in Ghana disentitles a widow to any viable or appreciable interest in her intestate husband's estate. This is so notwithstanding that the wife (or wives) in question would have made undeniably substantial contributions to the property ascribed to the husband as his self-acquired estate. To a large extent, the Ghanaian widow's (non-)inheritance situation reflects the experience of wives in many other African societies. In human rights terms, there exist global and African (regional) principles that philosophically censure this state of affairs. The influence of those principles on the phenomenon is, however, largely notional. Thus, the piecemeal changes that have been made to Ghana's inheritance law regime, eventually culminating in the passage of the Intestate Succession Law, 1985 (PNDC Law 111), have been impelled by national agitation against an inequitable customary inheritance institution that has for decades lagged behind socio-economic changes in the country. With minimal emendations in procedure and substance, the legislative regime introduced by Ghana's Law 111 should be a fair balance between the legitimate interests of families in the fortunes of their sons, and the prior obligations of these sons to ensure the material welfare of their widows (and dependent children). 